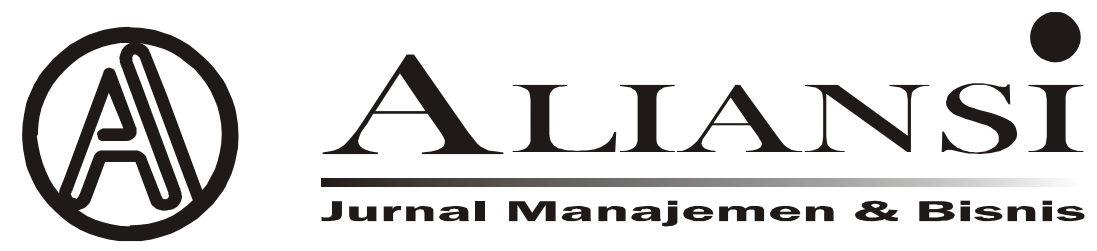

\title{
ANALISIS RAGAM PRODUK DAN KUALITAS INFORMASI TERHADAPMINAT BERBELANJA DISITUS ONLINE STORE SHOPEE (STUDI PADA PT REYCOM DOCUMENT SOLUSI DI JAKARTA)
}

Oleh : Arif Miharja, Danu Adi Kurniawan, Dian Maolani, Darrinh Rosharia

miharjabogor080479@gmail.com; danu.menteng2@gmail.com; maolani117@gmail.com;

darrinh.sagita@gmail.com

\begin{abstract}
The title of this research is Analysis of Product Variety and Quality of Information on Shopping Interests on the shopee online store site (Study on Employees of PT Reycome Document Solusi in Jakarta). Does the variety of products and quality of information affect the interest in shopping at the Shopee online store site? The purpose of this study was to determine the Analysis of Product Variety and Quality of Information on Shopping Interests.The population in this study were online users, namely employees of PT Reycome Document Solusi in Jakarta who had made purchases on the online Store Shopee site. According to the opinion of the roots, the sample requirements used in this study were 64 people. This research is an associative study using a quantitative approach. This research is categorized as survey research, in which the research instrument is a questionnaire. Validity test using CFA (Confirmatory Factor Analysis Model), using the SPSS application. The results of this study indicate that Product Variety has no significant effect on Shopping Interest on Shopee's online store site with test results $(t)$ of 0.970 greater than 0.05, and information quality has a significant effect on Shopping Interest on Shopee's online store sites with test results ( $t$ ) of 0.003 is less than 0.05. Thus the Information Quality variable $(X 2)$ is the most dominant variable influencing the shopping interest on the Shopee online store site.
\end{abstract}

Keywords: Variety of Products, Quality of Information, Interest in Shopping

\section{PENDAHULUAN}

Indonesia merupakan negara berkembang dimana masyarakatnya sangat terbuka dengan teknologi yang baru. Perkembangan teknologi informasi dan telekomunikasi di Indonesia sudah menyentuh seluruh kalangan masyarakat umum, pemerintah dan bisnis. Perkembangan teknologi informasi dan telekomunikasi juga membuat keadaan pasar semakin dinamis, mengharuskan para pelanggannya. Para pelaku bisnis harus menyikapi kedaan tersebut secara bijak. Salah satu informasi dan telekomunikasi yang mendukung kebutuhan adalah internet. Berbagai generasi sudah mengenal dan sebagian besar mampu menggunakannya. Internet mempunyai kegunaan yang sangat beragam dalam berbagai aspek kehidupan. Salah satunya adalah dapat digunakan untuk transaksi ekonomi yaitu jual beli online, yang lebih dikenal dengan sebutan e-Commerce.
Belanja secara online atau sering disebut ecommerce memiliki beberapa keunggulan yang dapat dirasakan bagi penggunanya seperti tidak perlu keluar rumah ataupun pergi ketempat belanja, yang sering dibutuhkan hanyalah memesan barang tersebut kemudian barang tersebut akan diantarkan kerumah, kedua keunggulan yang dirasakan adalah hemat waktu dalam membeli dan menghemat bahan bakar untuk berputar-putar dalam hal berbelanja, kita juga dapat mengontrol harga atau membandingkan harga dari beberapa tempat online shop. Ketiga online shop atau e-commerce selalu buka dalam waktu 24 jam, hal ini yang menguntungkan kita dalam menentukan waktu kapan kita akan melakukan aktivitas online shop.Tujuan penelitian ini dimaksudkan untuk mengetahui dan menganalisis ragam produk terhadap minat beli konsumen dalam berbelanja produk pada Toko Online Shopee dan juga untuk mengetahui dan 
menganalisis kualitas informasi terhadap minat beli konsumen dalam berbelanja produk pada Toko Online Shopee pada umumnya.

Dengan berkembangnya teknologi dan informasi sekarang ini banyak online shop yang bermunculan di berbagai kalangan, mulai dari remaja hingga kalangan orang dewasa. Barang yang ditawarkan juga bervariasi, mulai dari Pakaian Pria dan Wanita (Fashion), Handphone dan Aksesoris, Komputer dan Aksesoris, Perawatan dan Kesehatan, Perengkapan Rumah, Sepatu Pria dan Wanita, Tas Pria dan Wanita, Elektronik, Fotografi, serta Makanan dan Minuman. Semua barang tersebut dijual secara online melalui website, akun media sosial dan toko online diberbagai marketplace. Saat ini shopee sudah dapat mencakup wilayah diseluruh Indonesia bahkan dikota kecil. Dan sudah banyak Penjual yang menawarkan Produk nya pada aplikasi Shopee dan banyak juga Konsumen memilih Shopee sebagai tempat Belanja Online. Adapun cara Praktis pada Shopee melakukan Pembayaran, yaitu : Kartu Kredit/Debit Online, Indomart, Transfer Bank, Pembayaran Kredivo. Di Shopee untuk pembayaran via Transfer Bank sangat mudah karna ada sistem Pengecekan Otomatis, pembeli tidak perlu upload bukti transfer. Sedangkan Pembayaran Kredivo adalah kredit instan yang memberikan pembeli kemudahan untuk bayar dalam 30 hari tanpa bunga atau dengan fasilitas cicilan 3, 6 \& 12 bulan tanpa memerlukan kartu kredit. Omset Perusahaan tidak diketahui, tetapi adapun Omset beberapa Penjual di Shopee. Salah satunya ada Jordan Atik Bawazier, pemilik toko online @ PakaianOnline di Shopee, Jordan dapat mencapai Rp3,5 miliar setiap bulan.

Salah satu faktor yang menarik minat beli konsumen yaitu ragam produk. Perusahaan harus memiliki beragam produk yang dihasilkan karena dengan memiliki banyak pilihan produk maka reputasi perusahaan akan meningkat sehingga perusahaan akan mendapatkan predikat yang baik dimata pelanggan, bahkan tidak menutup kemungkinan bahwa produk dapat berekspansi di pasar global. Apabila produk yang dihasilkan sesuai dengan kebutuhan dan harapan pelanggan maka semakin banyak pelanggan yang tertarik untuk membeli produk diperusahaan tersebut.

Loyalitas pelanggan juga dapat diperoleh perusahaan apabila ragam produk yang dimiliki perusahaan memiliki keunikan tersendiri yang tidak dimiliki perusahaan lain dan meningkatkan kualitas produknya karena konsumen peduli terhadap kualitas barang yang dihasilkan oleh perusahaan.
Dunia bisnis maupun perusahaan dituntut untuk mempunyai sarana informasi yang dapat menunjang kegiatan bisnisnya, terutama perkembangan teknologi dalam bidang pemasaran agar produk mereka tetap dikenal konsumen sehingga memunculkan minat beli masyarakat. Salah satu strategi yang dapat dilakukan untuk menarik konsumen yaitu dengan memberikan kualitas informasi yang dapat merangsang respon pasar. Kualitas informasi diharapkan dapat membuat calon konsumen menggunakan suatu produk dan meninggalkan produk pesaing yang sejenis.

Kualitas informasi di dalam website e-commerce meliputi kelengkapan, akurasi, dan format sebagai aspek informasi yang disampaikan pada sistem $e$ commerce. Informasi yang berkualitas terbaik akan meningkatkan kepuasan maka dari itu kualitas informasi merupakan faktor utama yang menimbulkan kepuasan untuk pengguna. kualitas informasi yang dimaksud pada penelitian ini merupakan bagaimana cara perusahaan mengimformasikan mengenai produk secara detail, relevan, akurat dan tepat waktu sehingga konsumen merasa puas dengan informasi yang berikan.

Kualitas pelayanan memiliki peran yang penting dalam menciptakan kepuasan konsumen. Shopee telah melakukan upaya untuk meningkatkan kualitas pelayanan dengan menggunakan sistem yang terintegrasi dan terekam secara online. Namun temyata tidak sedikit pengguna yang mengeluhkan pada saat mengajukan komplain, sistem yang terlalu formal seperti pada saat pembeli harus menunggu balasan dari penjual. Hal yang sangat dikeluhkan adalah bagaimana customer service lambat dan tidak tegas dalam melayani komplain, sehingga banyak pengguna merasa dirugikan. Hal ini tentu akan berdampak negatif kepada kepuasan.

Lupiyoadi (2013:216) mengungkapkan apabila kualitas pelayanan yang diterima oleh konsumen lebih baik atau sama dengan yang dibayangkan, maka konsumen cenderung akan mencoba kembali. Akan tetapi, bila pelayanan yang diterima lebih rendah dari pelayanan yang diharapkan, maka konsumen akan kecewa dan akan menghentikan hubungannya dengan perusahaan yang bersangkutan. Konsumen akan beralih ke penyedia jasa lain yang lebih mampu memahami kebutuhan spesifik konsumen dan memberikan pelayanan yang lebih baik.

Berdasarkan pentingnya ragam produk dan kualitas informasi mempengaruhi keputusan pembelian. Maka perlu dilakukan penelitian tentang faktor-faktor tersebut dalam mempengaruhi minat berbelanja konsumen online, oleh karena itu peneliti 
tertarik untuk menguji analisis yang terjadi antar variabel dengan judul "analisisragam produk dan Kualitas Informasi Terhadap minat berbelanja disitus online store Shopee".

\section{METODE PENELITIAN Objek dan Waktu Penelitian}

1. Objek Penelitian

Penulis melakukan penelitian di PT Reycom Document Solusi, Jl Raya Bekasi Bizpark Commercial Estate Jakarta Timur yang pernah berbelanja di situs jual beli online Shopee.

2. Waktu Penelitian

Penelitian ini dilakukan pada bulan September 2019 sampai dengan Agustus 2020.

\section{Desain Penelitian}

Dalam penelitian ini, penulis menggunakan metode kuantitaif dengan pendekatan penelitian deskriptif dan analisis verifikatif, karena adanya variabel-variabel yang akan ditelaah hubungannya serta tsujuannya untuk menyajikan gambaran secara terstruktur, faktual, mengenai fakta-fakta hubungannya antar variabel yang diteliti.

Penelitian ini menggunakan Metode kuantitatif dengan mencari pengaruh antara variabel independen dengan variabel dependenuntuk mengetahui dan menganalisis pengaruhragam produk dan kualitas informasi terhadap minat berbelanja dionline store Shopee.

\section{Populasi dan Sampel}

\section{Populasi}

Adapun yang menjadi populasi dalam penelitian ini adalah karyawan PT Reycom Document Solusi (project Bank DBS \& Allianz, jakarta) yang sudah pernah berbelanja dionline store Shopee berjumlah 64 responden.

2. Sampel

Teknik sampling dalam penelitian ini adalah teknik pengambilan sempel jenuh,biasanya di lakukan jika populai diangap kecil atau kurang dari 100. Maka dari itu sempel yang digunakan dalam penelitan ini adalah keseluruhan karyawan PT Reycome Document Solusi Cabang Jakarta Timur sebanyak 64 responden.

\section{Teknik Pengumpulan Data}

Terdapat beberapa teknik pengumpulan data yang dilakukan oleh peneliti dalam penelitian ini teknik pengumpulan data yang digunakan adalah sebagai berikut:
1. Studi Kepustakaan

Pengumpulan data yang diperoleh melalui sumber-sumber tidak langsung yang dikaitkan dengan topik bahasan dari pihal lain secara tidak langsung, seperti penelitian sebelumnya yang pernah dilakukan, dokumen yang ada kaitannya dengan objek yang diteliti, misalnya:

a. Buku, yaitu data yang diperoleh literatur keperustakaan, portal berita, majalah, surat kabar dan sumber lain yang dianggap relevan dengan topik yang dibutuhkan dalam penelitian.

b. Jurnal, yaitu data pendukung yang berhubungan dengan penelitian yang membahas berbagai macam ilmu pendidikan serta penelitian yang dianggap relevan denga topik penelitian.

c. Internet, yaitu dengan cara mencari informasi-informasi yang berhubungandengan topik penelitian yang diaplikasikan di internet baik yang berbentuk jurnal, makalah ataupun karya ilmiah.

\section{Kuisioner}

Menurut Sugiono (2016: 142) Kuisioner merupakan teknik pengumpulan data yang dilakukan dengan cara memberi sepereangkat pertanyaan tertulis kepada responden untuk dijawabnya. Kuisioner merupakan teknik pengumpulan data yang efisien bila peneliti tahu dengan pasti variabel yang akan diukur dengan tahu apa yang bisa diharapkan dari responden. Skala yang dipakai dalam penyusunan kuesioner adalah skala Likert, Menurut Sugiyono (2016:93) Skala likert digunakan untuk mengukur sikap, pendapat, dan persepsi seseorang atau sekelompok orang tentang fenomena sosial, fenomena sosial ini telah ditetapkan secara spesifik oleh peneliti, yang selanjutnya disebut sebagai variabel penelitian.

\section{HASIL DAN PEMBAHASAN \\ Hasil}

\section{Uji Validitas}

Uji validitas kuesioner variabel (Ragam Produk, Kualitas Informasi dan MinatBerbelanja) penelitan ini, dilakukan di PT Reycome Document Solusi. Dengan menggunakan jumlah responden sebanyak 64 orang. 
Uji Validitas Variable RagamProduk.

1. Kaiser Meyer Olkin ( KMO )

KMO and Bartlett's Test

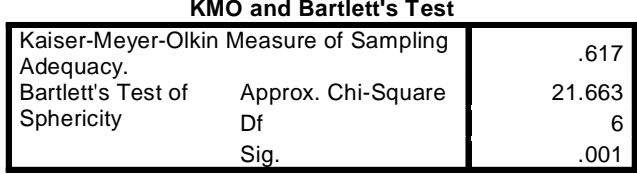

Sumber : Data diolah SPSS

Pada tabel KMO ( RagamProduk) di atas menunjukan hasil sebesar 0.617, hasil ini lebih besar dari > 0.5 hal ini menunjukan bahwa kecukupan data dalam penelitian selanjutnya. Pada table Barlett's test of sphericity menunjukan hasil Approx. Chi-Square sebesar 21.663 dan nilai Sig 0.001 . Hal ini menunjukan $\mathrm{H} 1$ di terima dengan nilai korelasi Sig di bawah $<0.5$.

2. Componen Matrix Variable Ragam Produk

\begin{tabular}{|l|c|}
\multicolumn{2}{c|}{ Component Matrix $^{\mathbf{a}}$} \\
\cline { 2 - 2 } \multicolumn{1}{|c|}{ Component $^{-1}$} \\
\hline $\mathrm{X} 1 \_1$ & .578 \\
$\mathrm{X} 1 \_2$ & .576 \\
$\mathrm{X} 1 \_3$ & .706 \\
$\mathrm{X} 1 \_4$ & .755 \\
\hline Extraction Method: Principal \\
Component Analysis. \\
a. 1 components extracted. \\
Sumber : Data diolah SPSS
\end{tabular}

Dari hasil tabel di atas menunjukan semua pertanyaan memenuhi di atas $>0.5$. Maka 4 butir pertanyaan akan di gunakan untuk penelitian selanjutnya.

\section{Uji Validitas Variable KualitasInformasi}

1. Kaiser Meyer Olkin ( KMO )

KMO and Bartlett's Test

\begin{tabular}{|c|c|c|}
\hline $\begin{array}{l}\text { Kaiser-Meyer-Olkin } \\
\text { Adequacy. } \\
\text { Bartlett's Test of } \\
\text { Sphericity }\end{array}$ & $\begin{array}{l}\text { Measure of Sampling } \\
\text { Approx. Chi-Square } \\
\text { Df } \\
\text { Sig. }\end{array}$ & $\begin{array}{r}.784 \\
90.293 \\
6 \\
.000 \\
\end{array}$ \\
\hline
\end{tabular}

Sumber : Data diolah SPSS

Pada tabel KMO ( KualitasInformasi) di atas menunjukan hasil sebesar 0.784 , hasil ini lebih besar dari $>0.5$ hal ini menunjukan bahwa kecukupan data dalam penelitian selanjutnya. Pada table Barlett's test of sphericity menunjukan hasil Approx. Chi-Square sebesar 90.293 dan nilai Sig 0.000 . Hal ini menunjukan $\mathrm{H} 1$ di terima dengan nilai korelasi Sig di bawah $<0.5$.
2. Componen Matrix Variable Kualitas Informasi

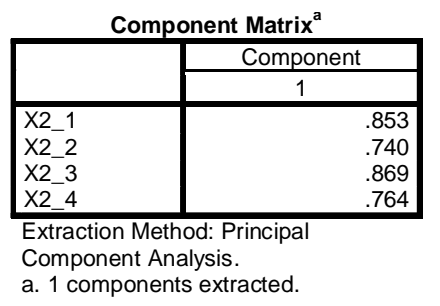

Sumber : Data diolah SPSS

Dari hasil tabel di atas menunjukan semua pertanyaan memenuhi di atas $>0.5$. Maka 4 butir pertanyaan akan di gunakan untuk penelitian selanjutnya.

\section{Uji Validitas Variable MinatBerbelanja}

1. Kaiser Meyer Olkin (KMO)

KMO and Bartlett's Test

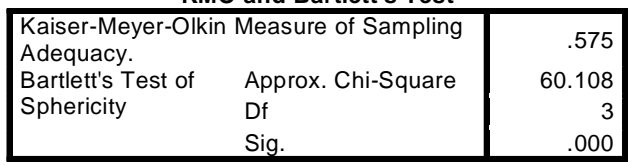

Sumber : Data diolah SPSS

Pada tabel KMO ( Punishment) di atas menunjukan hasil sebesar 0.575, hasil ini lebih besar dari $>0.5$ hal ini menunjukan bahwa kecukupan data dalam penelitian selanjutnya. Pada tabelBarlett's test of sphericity menunjukan hasil Approx. Chi-Square sebesar 60.108 dan nilai Sig 0.000 . Hal ini menunjukan H1 di terima dengan nilai korelasi Sig di bawah $<0.5$.

2. Componen Matrix Variable Minat Berbelanja

\begin{tabular}{|l|l|}
\hline \multicolumn{2}{|c|}{ Component Matrix ${ }^{\text {a }}$} \\
\cline { 2 - 3 } \multicolumn{1}{|c|}{ Component } \\
\cline { 2 - 3 } & \multicolumn{1}{|c|}{1} \\
\hline Y1 & .759 \\
Y3 & .917 \\
Extraction Method: Principal & .798 \\
Component Analysis. & \\
a. 1 components extracted. \\
Sumber : Data diolah SPSS
\end{tabular}

Dari hasil tabel di atas menunjukan semua pertanyaan memenuhi di atas $>0.5$. Maka 3 butir pertanyaan akan di gunakan untuk penelitian selanjutnya. 


\section{Uji Reliabilitas}

\section{a. Uji Reliabilitas RagamProduk}

Reliability Statistics

\begin{tabular}{|r|r|}
\hline $\begin{array}{c}\text { Cronbach's } \\
\text { Alpha }\end{array}$ & N of Items \\
\hline .549 & 4 \\
\hline
\end{tabular}

Sumber : Data diolah SPSS

Hasil table di atas menunjukan Cronbach's Alpha> 0,5 dengan nilai sebesar 0,549>0,5 maka kuesioner Ragam Produk dinyatakan reliable ataukonsisten.

\section{b. Uji Reliabilitas KualitasInformasi} Reliability Statistics

\begin{tabular}{|r|r|}
\hline $\begin{array}{c}\text { Cronbach's } \\
\text { Alpha }\end{array}$ & N of Items \\
\hline .817 & \\
\hline
\end{tabular}

Sumber : Data diolah SPSS

Hasil table di atas menunjukan Cronbach's Alpha> 0,5 dengan nilai sebesar 0,817>0,5 maka kuesioner KualitasInformasi dinyatakanreliable atau konsisten.

\section{c. Uji Reliabilitas MinatBerbelanja}

Tabel 4.10 Reliability Statistics

Tabel 4.10

Reliability Statistics

\begin{tabular}{|r|r|}
\hline $\begin{array}{c}\text { Cronbach's } \\
\text { Alpha }\end{array}$ & N of Items \\
\hline .767 & 3 \\
\hline
\end{tabular}

Sumber : Data diolah SPSS

Hasil table di atas menunjukan Cronbach's Alpha> 0,5 dengan nilai sebesar 0,767>0,5 maka kuesioner Minat Berbelanja dinyatakan reliable atau konsisten.

\section{Uji Hipotesis}

\section{Uji Normalitas}

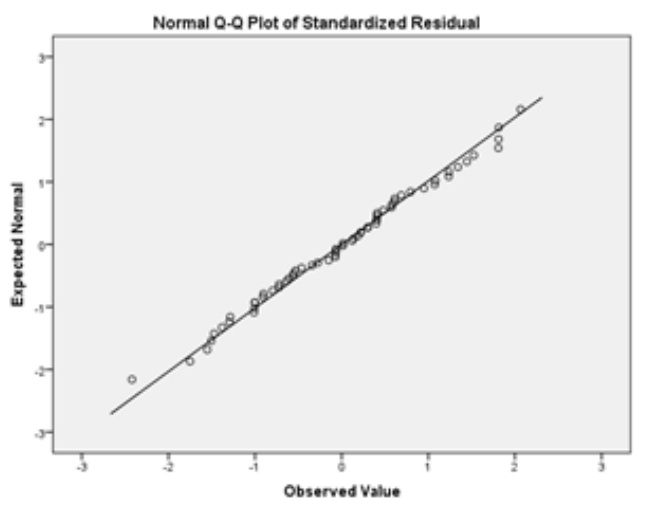

Tests of Normality

\begin{tabular}{|l|r|r|r|r|r|r|}
\hline \multirow{2}{*}{} & \multicolumn{3}{|c|}{ Kolmogorov-Smirnov } & \multicolumn{3}{|c|}{ Shapiro-Wilk } \\
\cline { 2 - 7 } & Statistic & df & Sig. & Statistic & Df & Sig. \\
\hline $\begin{array}{l}\text { Standardized } \\
\text { Residual }\end{array}$ & .064 & 64 & $.200^{*}$ & .989 & 64 & .840 \\
\hline
\end{tabular}

. This is a lower bound of the true significance.

a. Lilliefors Significance Correction

Sumber : Data diolah SPSS
Pengujian mengunakan Kolmogorov-Smirnov menunjukan Sig sebesar 0.200 dan lebih besar di bandikan 0,05 sehinga residual tidak berdistribusi normal.

Kendati demikian penelitian ini memilih menggunaka uji Q-Q Plot Residual, dimana data tersebar di garis diagonal sehinga seluruh variable di asumsikan distribusi normal.

\section{Uji Multikolinearitas}

\begin{tabular}{|ll|r|r|}
\hline \multirow{2}{*}{ Model } & \multicolumn{2}{|c|}{ Collinearity Statistics } \\
\cline { 3 - 4 } & & Tolerance & \multicolumn{1}{c|}{ VIF } \\
\hline 1 & (Constant) & & \\
& TOTAL_X1 & .795 & 1.258 \\
& TOTAL_X2 & .795 & 1.258 \\
\hline
\end{tabular}

Sumber : Data diolah SPSS

Hasil penelitian ini menunjukan bahwa nilai VIF $\mathrm{X}_{1}$ RagamProduk sebesar 1,258 dan $\mathrm{X}_{2}$ KualitasInformasi 1,258 nilai ini lebih kecil dari nilai 10 artinya baik variable $X_{1}$, dan $X_{2}$ tidak terjadi multikolinearlitas.

\section{Uji Heteroskedastisitas}

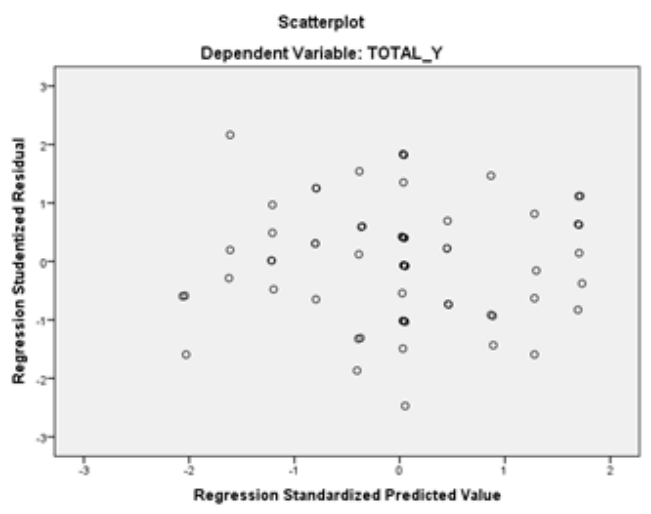

Dari gambar di atas menunjukan hasil pengujian Heteroskedastisitas menggunakan gambar Scatterplot dimana mengasilkan sebaran data yang secara acak dan tidak memiliki pola, serta titik-titik menyebar di atas 0 pada sumbu Y. Hasil ini menunjukan bahwa data dalam penelitian ini tidak terjadi heteroskedastisitas.

\section{Uji Koefisien Determinasi}

\begin{tabular}{l|r|r|r|r|}
\hline \multicolumn{1}{|c|}{ Model Summary $^{\text {Dodel }}$} & $\mathrm{R}$ & $\mathrm{R}$ Square & $\begin{array}{r}\text { Adjusted } \\
\text { R Square }\end{array}$ & $\begin{array}{r}\text { Std. Error of } \\
\text { the Estimate }\end{array}$ \\
\hline 1 & $.408^{\mathrm{a}}$ & .166 & .139 & 2.131 \\
\hline
\end{tabular}
a. Predictors: (Constant), TOTAL_X2, TOTAL_X1
b. Dependent Variable: TOTAL_Y
Sumber : Data diolah SPSS


Hasil penelitin ini menunjukan nilai $\mathrm{R}^{2} 0.408$ artinya variable $\mathrm{X}_{1}$ Ragam Produk dan $\mathrm{X}_{2}$ Kualitas Informasi mejelaskan variasi dari variabel Y minat Berbelanja sebersar 40,8\%. Sisanya $59.2 \%$ di jelaskan oleh variabel lainya.

\section{Uji Hipotesis}

1. Uji Keseluruhan Anova (Two-Way)

\begin{tabular}{|c|c|c|c|c|c|c|}
\hline \multicolumn{7}{|c|}{ ANOVA $^{\mathrm{a}}$} \\
\hline & & $\begin{array}{c}\text { Sum of } \\
\text { Squares }\end{array}$ & df & $\begin{array}{l}\text { Mean } \\
\text { Square }\end{array}$ & $\mathrm{F}$ & Sig. \\
\hline \multirow[t]{3}{*}{1} & Regression & 55.219 & 2 & 27.610 & 6.080 & $.004^{\circ}$ \\
\hline & Residual & 277.015 & 61 & 4.541 & & \\
\hline & Total & 332.234 & 63 & & & \\
\hline
\end{tabular}

Hasil penelitian ini menunjukan nilai sig uji Anova sebersar 0.004 lebih kecil di bandikan dengan 0.05 sehinga variable $\mathrm{X}_{1}$ RagamProduk dan $\mathrm{X}_{2}$ KualitasInformasi secara bersama sama dapat mempengaruhi Y MinatBerbelanja.

2. Uji Parsial ( $t$ )

\begin{tabular}{|c|c|c|c|c|c|c|}
\hline \multirow[b]{2}{*}{ Model } & & \multicolumn{2}{|c|}{$\begin{array}{l}\text { Unstandardized } \\
\text { Coefficients }\end{array}$} & \multirow{2}{*}{$\begin{array}{c}\begin{array}{c}\text { Standardized } \\
\text { Coefficients }\end{array} \\
\text { Beta } \\
\end{array}$} & \multirow[b]{2}{*}{$t$} & \multirow[b]{2}{*}{ Sig. } \\
\hline & & B & $\begin{array}{c}\text { Std. } \\
\text { Error }\end{array}$ & & & \\
\hline & (Constant) & 4.951 & 2.101 & & 2.356 & .022 \\
\hline & TOTAL_X1 & -.005 & .138 & -.005 & -.038 & .970 \\
\hline & TOTAL_X2 & .392 & .125 & .410 & 3.125 & .003 \\
\hline
\end{tabular}

Sumber : Data diolah SPSS

Hasil penelitian ini menunjukan nilai $\operatorname{Sig} \mathrm{X}_{1}$ Ragam Produk sebesar 0.970 lebih besar dari 0,05 yang mana diasumsikan variabelX $X_{1}$ tidak mempengaruhi Y Minat Berbelanja. Sedangkan nilai Sig $\mathrm{X}_{2}$ Kualitas Informasi sebesar 0.003 ,lebih kecil dari 0.05 yang mana diasumsikan variable $\mathrm{X}_{2}$ mempengaruhi $\mathrm{Y}$ Minat Berbelanja.

\section{Regresi Berganda}

\begin{tabular}{|ll|r|r|r|}
\multicolumn{5}{c|}{ Coefficients $^{\mathbf{a}}$} \\
\hline \multirow{2}{*}{ Model } & \multicolumn{2}{|c|}{$\begin{array}{c}\text { Unstandardized } \\
\text { Coefficients }\end{array}$} & $\begin{array}{c}\text { Standardized } \\
\text { Coefficients }\end{array}$ \\
\cline { 3 - 5 } & & \multicolumn{1}{|c|}{ B } & Std. Error & Beta \\
\hline 1 & (Constant) & 4.951 & 2.101 & \\
& TOTAL_X1 & -.005 & .138 & -.005 \\
& TOTAL_X2 & .392 & .125 & .410 \\
\hline
\end{tabular}

a. Dependent Variable: TOTAL_Y

Sumber : Data diolah SPSS

Dari tabel diatas maka dapat diketahui nilai-nilai sebagai berikut :

Konstanta (a) $=4.951$

RagamProduk $\left(\mathrm{X}_{1}\right)=-0.005$

KualitasInformasi $\left(\mathrm{X}_{2}\right)=0,392$
Dari hasil tersebut maka dapat diketahui model persamaan regresi linearnya adalah sebagai berikut:

$\mathrm{Y}=4.951-0.005 \mathrm{X}_{1}+0.392 \mathrm{X}_{2}$

1. Pada kondisi variabel $X_{1}$ dan $X_{2}$ konstan ( tidak berubah ) maka rata rata sekor disiplin kerja pegawai sebesar 4,951

2. Jika terjadi kenaikan sekor RagamProduksebesar 1 akan menurunkan sekor MinatBerbelanja sebesar 0.005 .

3. Jika terjadi kenaikan sekor KualitasInformasi sebesar 1 akan menaikan sekor MinatBerbelanja sebesar 0.392 .

\section{PEMBAHASAN}

1. Pengaruh Ragam Produk Terhadap Minat Berbelanja

Berdasarkan hasil pengujian Uji ( $\mathrm{t}$ ) secara individual pengaruh Reward terhadap Disiplin Kerja diperoleh angka signifikan sebesar 0.970> 0,05. Dapat disimpulkan bahwa $\mathrm{H} 0$ diterima (H1 ditolak),hal ini menunjukkan bahwa tidak ada pengaruh yang signifikan Ragam produk terhadap MinatBerbelanja di Online Store Shopee.

2. Pengaruh Kualitas Informasi Terhadap Minat Berbelanja

Berdasarkan hasil pengujian Uji ( t ) secara individual pengaruh KualitasInformasi terhadap Disiplin Kerja diperoleh angka signifikan sebesar $0.003<0,05$. Dapat disimpulkan bahwa $\mathrm{H} 1$ diterima (H0 ditolak),hal ini menunjukkan bahwa ada pengaruh yang signifikan KualitasInformasi terhadap MinatBerbelanja di Online Store Shopee.

3. Pengaruh Ragam Produk dan Kualitas Informasi Terhadap Minat Berbelanja

Berdasarkan hasil pengujian Uji Anova ( TowWay ) secara keseluruhan pengaruh Ragam Produk dan Minat berbelanja terhadap minat Berbelanja diperoleh angka signifikan sebesar $0.004<0,05$. Berdasarkan hasil ini, dapat disimpulkan bahwa $\mathrm{H} 1$ diterima (Ho ditolak), hal ini menunjukkan bahwa ada pengaruh yang signifikan Ragam Produk dan Kualitas Informasi terhadap Minat Berbelanja di Online Store Shopee. 


\section{SIMPULAN DAN SARAN}

\section{Simpulan}

1. Ragam Produk (X1) tidak berpengaruh terhadap Minat Berbelanja disitus Online store Shopee (Y), berdasarkan hasil pengujian yang sudah dilakukan oleh peneliti.

2. Kualitas Informasi (X2) berpengaruh terhadap Minat Berbelanja disitus Online store Shopee (Y), berdasarkan hasil pengujian yang sudah dilakukan oleh peneliti.

3. Ragam Produk(X1) dan Kualitas Informasi(X2) secara bersama - sama ada pengrauh signifikan terhadap Minat Berbelanja disitus Online store Shopee (Y). Berdasarkan pengujian Anova dengan nilai signifikansi $0.004<0.05$.

\section{Saran}

1. Bagi Penjual Didalam online store Shopee Didalam online shopping sebaiknya menyajikan informasi yang mencakup kaitannya dengan produk dan jasa yang ada pada online shopping. Informasi tersebut sebaiknya berguna dan relevan dalam memprediksi kualitas dan kegunaan produk. Informasi produk harus up to date untuk memuaskan kebutuhan konsumen. Hal tersebut dapat membantu pembeli didalam membuat keputusan, konsisten dan mudah dipahami.

2. Bagi rekan mahasiswa/I yang hendak melakukan penelitian serupa

Diharapkan dapat melakukan penelitian dengan menambahkan indikatorin dependen seperti : atribut produk (kualitas produk, kehandalan produk, desain produk dan tampilan yang menarik), atribut harga (terjangkaunya harga produk, daya saing harga produk) guna meningkatkan hubungan antara variable independen dan dependen.

3. Untuk penelitian selanjutnya

Diharapkan dapat berfokus pada produk yang tersegmentasi atau pada 1 toko online, misalnya, tentang produk sepatu dan produk pakaian.

\section{DAFTAR PUSTAKA}

Kotler, Philip dan Armstrong, Gary (2012). Prinsip prinsip Pemasaran Edisi 13 Jilid 1. Jakarta: Erlangga,

Sambas Ali Muhidin, spd,msi\& Dr. Maman Abdurahman, Mpd, 2017. Analisis Korelasi, Regresi danJalurDalamPenelitian, CV Pustaka

Sugiyono (2016), Metode Penelitian Kuantitatif, Kualitatif dan R\&D. Bandung: Penerbit Alfabeta

Alma, 2011. Manajemen Pemasaran dan Pemasaran Jasa. Cetakan Kesembilan, Yogyakarta: PenerbitAlfabeta

McKechnie, 2012. PerilakuKonsumen. Yogyakarta : Penerbit ANDI.

Hendryadi, 2018. Metode Riset Untuk Mahasiswa bisnis dan Manajemen.

Hsu, Pei-fang, Hsiuju Rebecca, and Jung-ching Chung. (2015). "Information \& Management Assessing ERP Post-Implementation Success at the IndividualLevel/ : Revisiting the Role of Service Quality.” Information \& Management 52(8):925-42

Kotler, Philip dan Keller, Kevin Lane. Manajemen PemasaranEdisi 13 Jilid 1 Jakarta: Erlangga, 2019

Stanton, William J. 2010. Prinsip pemasaran. Alih bahasa : Yohanes Lamarto Penerbit Erlangga, Jakarta.

Sunyoto, Danang. 2013. Dasar - Dasar Manajemen Pemasaran. Yogyakarta: CAPS 
